\title{
Factors of angiogenesis and placental hormones in pregnant women with arterial hypertension
}

\author{
O. V. Deinichenko*B,C,D, Yu. Ya. Krut ${ }^{A, E, F}$
}

Zaporizhzhia State Medical University, Ukraine

A - research concept and design; B - collection and/or assembly of data; C - data analysis and interpretation; D - writing the article; $\mathrm{E}$ - critical revision of the article; $\mathrm{F}$ - final approval of the article

Key words: factors of angiogenesis, placental hormones, pregnancy, arterial hypertension.

Pathologia 2019; 16 (3), 368-372 DOI: 10.14739/2310-1237. 2019.3.188891

*E-mail: agol0309@gmail.com
The changes of the factors of angiogenesis and hormones of pregnancy in pregnant women with hypertension of I and II stages has been studied inadequately and their interaction in such patients is not fully elucidated at present time.

Aim. To detect peculiarities of angiogenesis factors and placental hormones in pregnant women with arterial hypertension I and II grades in comparison with results of healthy pregnant women.

Materials and methods. A one-time study of pregnant women was performed in pregnancy of 12-13 weeks in all groups. 88 pregnant women were inspected. The 1st basic group consisted of 28 pregnant women with $\mathrm{AH}$ of I grade; the 2nd group consisted of 33 pregnant women with $\mathrm{AH}$ of II grade; the comparison group included 27 women without $\mathrm{AH}$. The following hormones were determined: HCG, PG, E. Among the angiogenesis indices, the placental growth factor (PGF), as a pro-angiogenic factor and placental soluble fms-like tyrosine kinase (sFlt-1) was determined as an anti-angiogenic factor, sFlt-1/PGF ratio was also estimated. Statistical analysis was done by using Statistica for Windows 13 (StatSoft Inc., № JPZ804I382130ARCN10-J).

Results. Pregnant women in 1st group were the youngest: the average age was $26.4 \pm 0.8$ years versus $33.8 \pm 0.6$ years in 2nd group and $32.0 \pm 1.0$ years in control group, $P<0.001$. PGF levels were decreased in both $1 \mathrm{st}(17.5 \pm 3.4 \mathrm{pg} / \mathrm{ml})$ and 2nd groups $(13.5 \pm 2.5 \mathrm{pg} / \mathrm{ml})$ in comparison with results in 3rd group $(46.1 \pm 7.0 \mathrm{pg} / \mathrm{ml}), P<0.001$. We didn't find statistical differences between results of women with $\mathrm{AH}$ of I and II degree, $\mathrm{P}>0.05$. Contrary to previous results, $\mathrm{sFlt}-1$ levels were increased in both 1 st and $2 \mathrm{nd}$ groups, $\mathrm{P}<0.05: 1703.1 \pm 99.2 \mathrm{pg} / \mathrm{ml}$ in $1 \mathrm{st}$ group and $1673.7 \pm 93.5 \mathrm{pg} / \mathrm{ml}$ in $2 \mathrm{nd}$ group versus $1384.4 \pm 77.1 \mathrm{pg} / \mathrm{ml}$ in control group, but they weren't different between basic groups, $\mathrm{P}>0.05$. As a result, sFIt-1/PGF ratio level was increased in both $1 \mathrm{st}(273.3 \pm 54.6$ units) and 2 nd ( $415.8 \pm 79.0$ units) groups in comparison with control (46.6 \pm 9.4 units), $P<0.001$. We didn't set statistical differences in hormones levels among pregnant patients. PGF level was connected with $E(r=-0.54, P<0.01)$ and HCG $(r=-0.42, P<0.05)$ levels in pregnant women with $A H$ of I degree. It was connected with HCG level in control group, but this correlation was contrary: $r=+0.63, P<0.001$.

Conclusions. Pregnant women with $\mathrm{AH}$ in I trimester have disturbances in balance between pro-angiogenic and anti-angiogenic factors with prevalence of sFlt-1 and reducing of PGF in blood serum. Due to such disbalance in pregnant women with AH of I grade correlation between angiogenesis factors and hormones changed from direct to inverse.
Киючові слова: фактори ангіогенезу, плацентарні гормони, вагітність, артеріальна гіпертензія.

Патологія. - 2019. T. 16, № 3(47). -

C. 368-372

\section{Фактори ангіогенезу та плацентарні гормони у вагітних з артеріальною гіпертензією}

\section{О. В. Аейніченко, Ю. Я. Круть}

Зміни фракторів ангіогенезу та гормонів вагітності у жінок із гіпертензією (АГ) I та ІІ ступенів вивчені недостатньо, а їхня взаємодія в таких пацієнток достеменно не встановлена.

Мета роботи - визначити особливості факторів ангіогенезу та плацентарних гормонів у вагітних жінок з АГ I та II ступенів порівняно з результатами здорових вагітних.

Матеріали та методи. Виконали одномоментне дослідження вагітних у термінах вагітності 12-13 тижнів у всіх групах. Обстежили 88 вагітних: у 1 основну групу ввійшли 28 вагітних з АГ І ступеня; 2 група включала 33 вагітних із АГ ІІ ступеня; у групу порівняння ввійшли 27 вагітних жінок без АГ. Досліджували сироватку крові, визначали гормони: хоріонічний гонадотропін (ХГЛ), прогестерон (ПГ), естрадіол (Е). Серед показників ангіогенезу досліджували плацентарний фрактор росту (PGF) як про-ангіогенний фактор, а також плацентарну розчинну тирозинкіназу (sFlt-1) як анти-ангіогенний фактор; обчислювали sFlt-1/PGF співвідношення. Статистичний аналіз виконали за допомогою програми Statistica for Windows 13 (StatSoft Inc., № JPZ804I382130ARCN10-J).

Результати. Вагітні 1 групи були наймолодшими - їхній середній вік становив 26,4 \pm 0,8 року проти 33,8 \pm 0,6 року в жінок 2 групи та $32,0 \pm 1,0$ року у вагітних контрольної групи, p < 0,001. Рівні PGF були зниженими в $1(17,5 \pm 3,4$ пг/мл) і 2 (13,5 $\pm 2,5$ пг/мл) групах порівняно з показниками 3 (46,1 $\pm 7,0$ пг/мл) групи, p < 0,001. Не встановили статистичну різницю між показниками жінок із АГ I та II ступенів, p>0,05. На відміну від цих даних, рівні FIt-1 були підвищеними в 1 і 2 групах, p < 0,05: 1703,1 \pm 99,2 пг/мл у 1 групі та 1673,7 \pm 93,5 пг/мл у 2 групі проти 1384,4 \pm 77,1 пг/мл у контрольній групі, але вони не відрізнялися в пацієнток основних груп, $p>0,05$. Як результат, співвідношення sFlt-1/PGF було

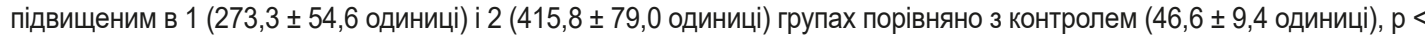
0,001 . Не виявили статистично значущу різницю між групами вагітних за рівнями плацентарних гормонів. Рівні PGF були пов'язані з рівнями $E(r=-0,54, p<0,01)$ та ХГЛ $(r=-0,42, p<0,05)$ у вагітних з АГ I ступеня. Рівень PGF також був пов'язаний із рівнем ХГЛ у контрольній групі, але ця кореляція була іншого напряму $-r=+0,63, p<0,001$. 
Висновки. У вагітних з АГ у I триместрі визначили порушення балансу між про-ангіогенними та анти-ангіогенними факторами з переважанням sFIt-1 і зниженням PGF у сироватці крові. У зв'язку з таким дисбалансом у вагітних із АГ I ступеня змінюється на протилежну кореляція між факторами ангіогенезу та гормонами.

\section{Факторы ангиогенеза и плацентарные гормоны у беременных с артериальной гипертензией}

\section{Е. В. Аейниченко, Ю. Я. Круть}

Изменения фракторов ангиогенеза и гормонов беременности у женщин с артериальной гипертензией (АГ) I и II степеней изучены недостаточно, а их взаимодействие у таких пациенток полностью не определено.

Цель работы - установить особенности факторов ангиогенеза и плацентарных гормонов у беременных с АГ I и II степеней в сравнении с результатами здоровых беременных.

Материалы и методы. Провели одномоментное исследование беременных в сроках беременности 12-13 недель во всех группах. Обследовали 88 беременных: 1 основная группа состояла из 28 беременных с АГ I степени; 2 группа включала 33 беременных с АГ II степени; в группу сравнения вошли 27 беременных без АГ. Исследовали сыворотку крови, определяли гормоны: хорионический гонадотропин (ХГЧ), прогестерон (ПГ), эстрадиол (Е). Среди показателей ангиогенеза исследовали плацентарный фрактор роста (PGF) как про-ангиогенный фактор, а также плацентарную растворимую тирозинкиназу (sFlt-1) как анти-ангиогенный фактор; вычисляли sFlt-1/PGF соотношение. Статистический анализ провели с помощью программы Statistica for Windows 13 (StatSoft Inc., № JPZ804I382130ARCN10-J).

Результаты. Беременные 1 группы были самыми молодыми - их средний возраст составил 26,4 \pm 0,8 года против $33,8 \pm 0,6$ года женщин 2 группы и $32,0 \pm 1,0$ года у беременных контрольной группы, $p<0,001$. Уровни PGF были сни-

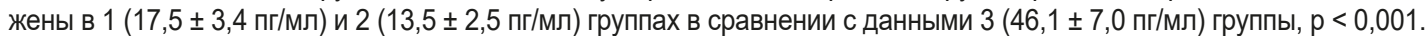
Не установлена статистическая разница между результатами женщин с АГ I и II степеней, $p>0,05$. В отличие от этих данных, уровни Flt-1 были повышенными в 1 и 2 группах, p < 0,05: 1703,1 1 99,2 пг/мл в 1 группе и 1673,7 \pm 93,5 пг/мл во 2 группе против 1384,4 \pm 77,1 пг/мл в контрольной группе, но они не отличались у пациенток основных групп, $p>$ 0,05. Как результат, соотношение sFIt-1/PGF было повышенным в 1 (273,3 $\pm 54,6$ единицы) и 2 (415,8 \pm 79,0 единицы) группах сравнительно с контролем (46,6 $\pm 9,4$ единицы), $p<0,001$. Не установлена статистически значимая разница между группами беременных по уровням плацентарных гормонов. Уровни PGF связанны с уровнями $E(r=-0,54, p<$ $0,01)$ и ХГЧ $(r=-0,42, p<0,05)$ у беременных с АГ I степени. Уровень PGF также связан с уровнем ХГЧ в контрольной группе, хотя эта корреляция была обратной $-r=+0,63, p<0,001$.

Выводы. У беременных с АГ в I триместре установлено нарушение баланса между про-ангиогенными и анти-ангиогенными фракторами с преобладанием sFlt-1 и снижением PGF в сыворотке крови. В связи с таким дисбалансом у беременных с АГ I степени меняется на обратную корреляция между фракторами ангиогенеза и гормонами.

Cardiovascular diseases have the first place among extragenital diseases in the structure of the causes of perinatal morbidity and mortality. Arterial hypertension (AH) occupies a leading position among these cardiovascular diseases. $\mathrm{AH}$ promotes the development of long-term vascular and metabolic disorders $[1,2]$. There is a decrease in placental blood flow in pregnant women with $\mathrm{AH}$ due to changes in the functioning of the cardiovascular system. Disturbances of the normal relationship between vasodilators and vasoconstrictors in pregnant women with $\mathrm{AH}$ are accompanied by dysregulation of vascular tone and leads to placental insufficiency $[3,4]$. One of the leading theories of placental insufficiency is vascular-endothelial dysfunction theory. Endothelial cells of vessels synthesize a large number of biologically active substances that are involved in providing a variety of processes in the physiological and pathological gestational processes [5].

The activity of placental angiogenesis is controlled by a spectrum of growth factors with pro-angiogenic and anti-angiogenic properties. The placental growth factor (PGF) in the first trimester of pregnancy stimulates the synthesis of trophoblastic DNA, increases the number of trophoblast cells and improves the conditions for its infestation. During the third trimester of pregnancy PGF expression reaches a maximum of 28-30 weeks of gestation, gradually increasing from the first to the se- cond trimester of pregnancy [6,7]. Anti-angiogenic factors include placental soluble fms-like tyrosine kinase (sFlt-1). It counteracts the action of PGF on specific receptors [8]. The imbalance between pro- and anti-angiogenic factors contributes to placental insufficiency [6].

Estradiol $(E)$ is the main hormone of pregnancy. Reduced $E$, its constantly low concentration, or insufficient growth indicate a violation of the fetoplacental complex. Human chorionic gonadotropin (HCG) appears in the blood of the mother on 8-9 days after fertilization of the egg. During the first trimester of pregnancy, HCG levels are rapidly increasing, doubling every 2-3 days, reaching its maximum at 8 th- 10 th weeks of gestation. After that, its content is somewhat reduced and remains constant during the second half of pregnancy [9]. Progesterone (PG) improves the conditions for trophoblast migration in 1st-2nd gestational trimesters by stimulating the growth and remodeling of the coiled arteries of the uterus, increasing the expression of the vascular endothelial growth factor and its receptor [10].

The changes of the factors of angiogenesis and hormones of pregnancy in pregnant women with hypertension of I and II stages has been studied inadequately and their interaction in such patients is not fully elucidated at present time.
Киючевые слова: факторы ангиогенеза, плацентарные гормоны, беременность, артериальная гипертензия.

Патология. - 2019. T. 16, № 3(47). -

C. $368-372$ 


\section{Aim}

To detect peculiarities of angiogenesis factors and placental hormones in pregnant women with arterial hypertension I and II grades in comparison with the results of healthy pregnant women.

\section{Materials and methods}

Criteria for inclusion in the study: pregnancy, the presence of $\mathrm{AH}$ of I and II grades. Criteria for exclusion from the study: $\mathrm{AH}$ of III grade, diabetes mellitus, multiple pregnancy, chromosomal and genetic disorders, thrombophilia, perinatal infections, systemic connective tissue diseases, heart disease (heart defects, myocarditis), anemia of moderate to severe degrees, diseases of the lungs, oncological diseases, pregnancy that comes with assisted reproductive technology.

A one-time study of pregnant women was performed in pregnancy of 12-13 weeks in all groups. 88 pregnant women were inspected. The 1 st basic group consisted of 28 pregnant women with $\mathrm{AH}$ of I grade; the 2 nd group consisted of 33 pregnant women with $\mathrm{AH}$ of II grade; the comparison group included 27 women without $\mathrm{AH}$. Anamnesis, general clinical examination, blood pressure measurement, standard obstetric and gynecological examination according to clinical protocols were done in all cases. $\mathrm{AH}$ was diagnosed according to the existing clinical protocols.

The following hormones were determined: HCG, PG, E. Among the angiogenesis indices, the placental growth factor (PGF), as a pro-angiogenic factor and placental soluble fms-like tyrosine kinase (sFlt-1) was determined as an anti-angiogenic factor, sFIt-1/PGF ratio was also estimated. Research of hormones and factors of angiogenesis was performed on the basis of the Educational Medical Laboratory Center (the head is professor A. V. Abramov) of Zaporizhzhia State Medical University. For this purpose, the microplate reader Sirio-S (Seac, Italy) was used. Blood serum was examined. Indicators of hormones and factors of angiogenesis were performed using immuno-enzymatic methods in accordance with the relevant instructions using the appropriate sets of reagents: HCG, PG, E (Monobind Inc, USA); PGF and sFlt-1 (R\&D systems, Inc, USA\&tCanada).

Statistical analysis was done by using Statistica for Windows 13 (StatSoft Inc., № JPZ804I382130ARCN10-J). Normality of data distribution in groups was determined by Shapiro-Wilk method. Results were presented as mean \pm error of mean $(\mathrm{M} \pm \mathrm{m})$. Differences between groups were estimated by Student's criterion. To determine the relationship between the indicators, the correlation coefficient was calculated using the Spearmen method; statistically significant results were considered with a coefficient of more than 0.3 and with a level of $P$ $<0.05$.

The Bioethical committee of Zaporizhzhia State Medical University decided that scientific work corresponds to all the requirements of moral and ethical standards (Protocol number 2 from 03/22/2017).

\section{Results}

We could say, that pregnant women in 1st group were the youngest: the average age was $26.4 \pm 0.8$ years versus $33.8 \pm 0.6$ years in 2 nd group and $32.0 \pm 1.0$ years in control group, $\mathrm{P}<0.001$. It may be explained, that progression of $\mathrm{AH}$ needs some time from beginning. PGF levels were decreased in both $1 \mathrm{st}(17.5 \pm 3.4 \mathrm{pg} / \mathrm{ml})$ and 2 nd groups $(13.5 \pm 2.5 \mathrm{pg} / \mathrm{ml})$ in comparison with results in control group $(46.1 \pm 7.0 \mathrm{pg} / \mathrm{ml}), P<0.001$. We didn't find statistical differences between results of women with $\mathrm{AH}$ of $\mathrm{I}$ and II degree, $\mathrm{P}>0.05$. Contrary to previous results, sFlt-1 levels were increased in both 1st and 2nd groups, $P<0.05: 1703.1 \pm 99.2 \mathrm{pg} / \mathrm{ml}$ in 1 st group and $1673.7 \pm 93.5 \mathrm{pg} / \mathrm{ml}$ in 2 nd group versus $1384.4 \pm 77.1$ $\mathrm{pg} / \mathrm{ml}$ in control group, but they weren't different between basic groups, $P>0.05$. As a result, sFlt-1/PGF ratio level was increased in both $1^{\text {st }}(273.3 \pm 54.6$ units $)$ and 2 nd (415.8 \pm 79.0 units) groups in comparison with control $(46.6 \pm 9.4$ units), $\mathrm{P}<0.001$. But it was the highest in pregnant women with $\mathrm{AH}$ of II grade (Fig. 1).
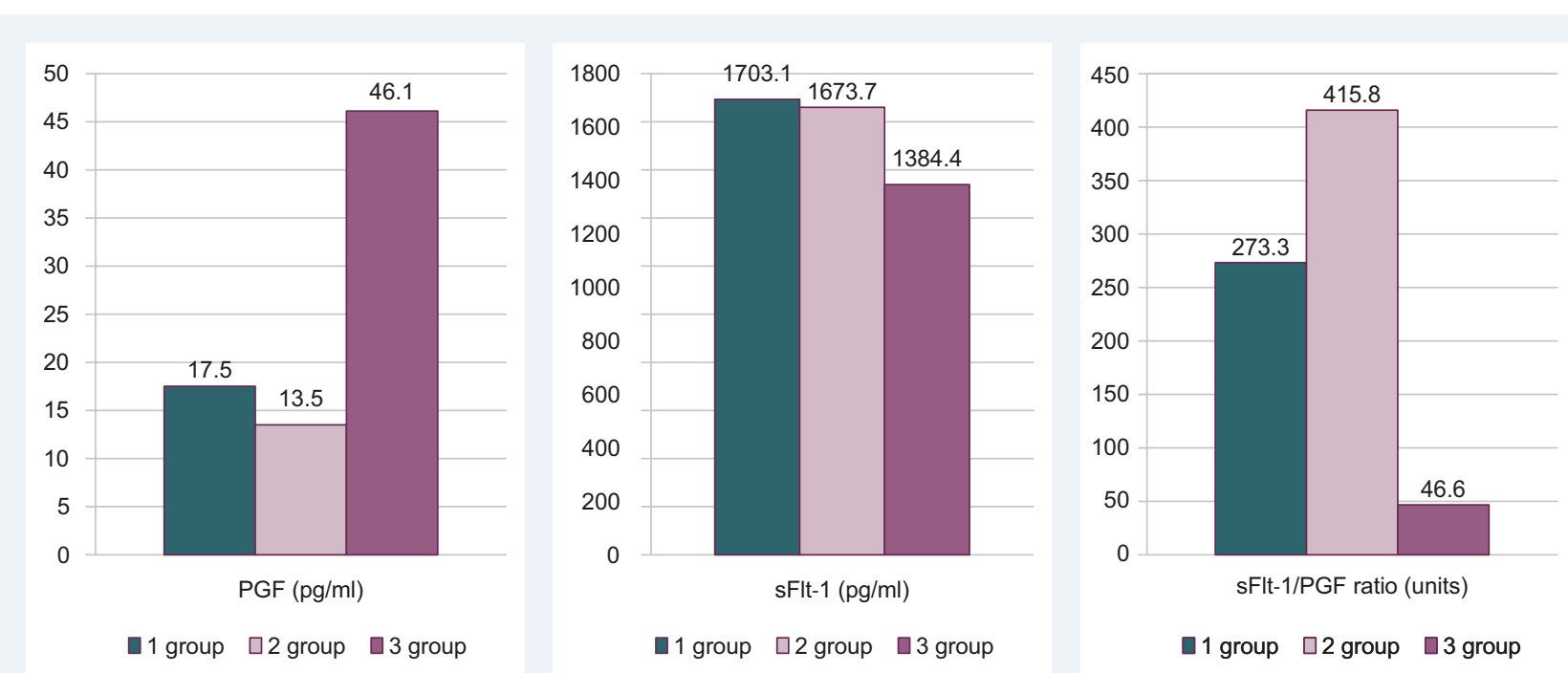

Fig. 1. Angiogenesis factors and sFIt-1/PGF ratio in groups of women. 
Table 1. Hormones levels in groups of women, $\mathrm{M} \pm \mathrm{m}$

\begin{tabular}{|c|c|c|c|c|}
\hline Indicators, units & $\begin{array}{l}\text { 1st group, } \\
n=28\end{array}$ & $\begin{array}{l}\text { 2nd group, } \\
n=33\end{array}$ & $\begin{array}{l}\text { Control group, } \\
n=27\end{array}$ & $P$ \\
\hline $\mathrm{PG}, \mathrm{ng} / \mathrm{ml}$ & $32.0 \pm 2.4$ & $38.6 \pm 3.0$ & $36.1 \pm 2.7$ & $>0.05$ \\
\hline $\mathrm{E}, \mathrm{pg} / \mathrm{ml}$ & $2449.1 \pm 228.7$ & $2522.5 \pm 230.4$ & $2836.2 \pm 268.6$ & $>0.05$ \\
\hline $\mathrm{HCG}, \mathrm{ng} / \mathrm{ml}$ & $516.1 \pm 21.9$ & $513.3 \pm 22.6$ & $521.3 \pm 23.0$ & $>0.05$ \\
\hline
\end{tabular}

We didn't dedicate statistical differences among pregnant patients in hormones levels, $\mathrm{P}>0.05$ for all indicators. There were only a little reducing in $P G$ level in women with $\mathrm{AH}$ of I degree: 1.2 times as compared to $2^{\text {nd }}$ group and 1.1 times as compared to control group (Table 1).

PGF level was connected with $E(r=-0.54, P<0.01)$ and $\mathrm{HCG}(r=-0.42, P<0.05)$ levels in pregnant women with $\mathrm{AH}$ of I degree. It was connected with $\mathrm{HCG}$ level in control group, but this correlation was contrary: $r=+0.63$, $P<0.001$. We couldn't detect any correlations between indicators in patients from 2nd group, $\mathrm{P}>0.05$.

\section{Discussion}

We detected reducing of PGF and growing of sFlt-1 (as sFIt-1/PGF ratio) in pregnant women with $\mathrm{AH}$ of both I and II grades. The similar results had group of authors $[11,12]$. But these authors examined patients in II trimester of pregnancy. PGF sFlt-1 levels were also detected [13], they included them to prognosis of preeclampsia and showed their levels in 1st trimester. The highest sFlt1/PGF ratio was in pregnant women with $\mathrm{AH}$ of II grade, that may indicate progression of pathological changes after several years of living with arterial hypertension. But we didn't find any statistical differences in hormones levels between groups of patients. Another results were received by groups of scientists $[9,14,15]$. They found decrease of $E$ levels in pregnant women. Contrary to literature results we examined both angiogenesis factors and hormones. We defined inverse correlations between PGF levels and two hormones levels ( $E$ and $H C G$ ) in women with $\mathrm{AH}$ of I grade versus to direct correlation between this pro-angiogenesis factor and HCG in control group. It may indicate disturbances in cooperation of such indicators in case of $\mathrm{AH}$ beginning. We suppose, such changes may lead to development of placental insufficiency in future. That's why treatment/prophylaxis of it should be administered to pregnant women with $\mathrm{AH}$ of I grade in I trimester.

\section{Conclusions}

1. Pregnant women with $\mathrm{AH}$ in I trimester have disturbances in balance between pro-angiogenic and anti-angiogenic factors with prevalence of sFlt-1 and reducing of PGF in serum.

2. Due to such disbalance in pregnant women with $\mathrm{AH}$ of I grade correlation between angiogenesis factors and hormones changed from direct to inverse.

Future researches plans. We plan to find features of angiogenesis factors and hormones changes in patients with arterial hypertension with fetal growth retardation and to detect early indicators of such complication of placental insufficiency.
Conflicts of interest: authors have no conflict of interest to declare. Конфмікт інтересів: віАсутній.

Надійшла Ао редакції / Received: 11.06.2019

Після Аоопрацювання / Revised: 13.11.2019

Прийнято Ао Аруку / Accepted: 14.11.2019

Information about authors:

Deinichenko O. V., Postgraduate Student of the Department of Obstetrics and Gynecology, Zaporizhzhia State Medical University, Ukraine.

Krut Yu. Ya., MD, PhD, DSc, Professor, Head of the Department of Obstetrics and Gynecology, Zaporizhzhia State Medical University, Ukraine.

\section{Відомості про авторів:}

Аейніченко О. В., аспірант каф. акушерства та гінекології, Запорізький Аержавний медичний університет, Україна. Круть Ю. Я., А-р меА. наук, професор, зав. каф. акушерства та гінекології, Запорізький Аержавний медичний університет, Україна.

\section{Сведения об авторах:}

Аейниченко Е. В., аспирант каф. акушерства и гинекологии, Запорожский государственный меАицинский университет, Украина.

Круть Ю. Я., А-р меА. наук, профессор, зав. каф. акушерства и гинекологии, Запорожский государственный медицинский университет, Украина.

\section{References}

[1] Padyganova, A. V. Chicherina, E. N. Kardiometabolicheskii risk u beremennykh s khronicheskoi arterial'noi gipertenziei i sovremennye podkhody k ego korrektsii [Cardiometabolic risk and modern methods of its correction in pregnant women with chronic arterial hypertension]. Rossiiskii kardiologicheskii zhurnal, 5, 75-80. [in Russian].

[2] Bramham, K., Parnell, B., Nelson-Piercy, C., Seed, P. T., Poston, L., \& Chappell, L. C. (2014). Chronic hypertension and pregnancy outcomes: systematic review and meta-analysis. Bmj-British Medical Journal, 348. https://doi.org/10.1136/bmj.g2301

[3] Korol, T. M. (2013). Fetoplatsentarna nedostatnist (FPN) - aktualna problema medytsyny. Kliniko-etiopatohenetychni kryterii diahnostyky, likuvannia ta profilaktyky [Fetoplacental insufficiency (FPN) - actual problem of medicine. Clinical-etiopathogenetical diagnostic criteria, tretment and prevention]. Visnyk problem biolohii i medytsyny, 1(2), 49-54. [in Ukrainian].

[4] Alekseeva, L. L., Borgolov, A. V., Mangataeva, M. R., Afanas'eva, O. M., \& Radnaeva S. A. (2008). Mekhanizm formirovaniya KhFPN pri arterial'noi gipertenzii u beremennykh zhenshchin [The mechanism of chronicle fetoplacental deficiency forming due to arterial hypertension of the pregnant women]. Vestnik Buryatskogo gosudarstvennogo universiteta, 12, 82-86. [in Russian].

[5] Orlov, A. V., \& Kudinova, E. I. Etiopatogeneticheskie aspekty razvitiya platsentarnoi nedostatochnosti i zaderzhki rosta ploda [Aspects etiopatogenesis of the development to insufficiency of placenta and fetal growth retardation]. Zhurnal fundamental'noi meditsiny i biologii, 4, 4-10. [in Russian].

[6] Fomina, M. P., Divakova, T. S., Rzheusskaya, L. D. (2014). Endotelial'naya disfunktsiya i balans angiogennykh faktorov u beremennykh $s$ platsentarnymi narusheniyami [Effect of otilonium bromide on intensity of chronic abdominal pain]. Meditsinskie novosti, 3, 63-67. [in Russian].

[7] Makarov, O. V., Volkova, E. V., Dzhokhadze, L. S. (2012). Rol' pro-i antiangiogennykh faktorov $v$ diagnostike razlichnykh form gipertenzivnykh sostoyanii pri beremennosti [Role of pro- and antiangiogenic factors in 
the diagnosis of different forms of hypertensive states of pregnancy]. Rossiyskiy vestnik akushera-ginekologa, 3, 15-20. [in Russian].

[8] Goryunova, A. G., Simonova, M. S., \& Murashko, A. V. (2016). Sindrom zaderzhki rosta ploda i adaptatsiya platsentyi [Fetal growth retardation syndrome and adaptation of placenta]. Arhiv akusherstva i ginekologii im. V.F. Snegireva, 3(2), 76-80. [in Russian]. https://doi. org/10.18821/2313-8726-2016-3-2-76-80

[9] Trishkin, A. G., Novikova, O. N., Artymuk, N. V., Ushakova, G. A., Kiprina, E. S., \& Bikmetova, E. S. (2012). Gormonalno-metabolicheskie osobennosti fetoplatsentarnogo kompleksa pri zaderzhke rosta ploda [Hormonal and metabolic characteristics of fetoplacental complex in women with fetal growth restriction]. Mat'i ditya v Kuzbasse, 1, 59-63. [in Russian].

[10] Divakova, T. S., \& Famina, M. P. (2014). Osobennosti vliyaniya didrogesterona i atsetilsalitsilovoy kislotyi na platsentarnyiy angiogenez pri oslozhnennoy beremennosti [Effects of dydrogesterone and acetylsalicylic acid on placental angiogenesis in complicated pregnancies]. Meditsinskie novosti, 2, 67-72. [in Russian].

[11] Volkova, E. V., Lysyuk, E. Yu., Dzhokhadze, L. S., \& Makarov, O. V. (2013). Osobennosti izmeneniy pro- i antiangiogennyih faktorov u beremennyih s hronicheskoi arterial'noi gipertenziey [Specific features of changes in pro- and antiangiogenic factors in pregnant women with chronic arterial hypertension]. Rossiyskiy vestnik akushera-ginekologa, 3, 9-13. [in Russian]

[12] Zeisler, H., Llurba, E., Chantraine, F., Vatish, M., Staff, A. C., Sennstrom, M., ... Verlohren, S. (2016). Predictive Value of the sFIt-1:PIGF Ratio in Women with Suspected Preeclampsia. New England Journal of Medicine, 374(1), 13-22. https://doi.org/10.1056/NEJMoa1414838

[13] Youssef, A., Righetti, F., Morano, D., Rizzo, N., \& Farina, A. (2011). Uterine artery Doppler and biochemical markers (PAPP-A, PIGF, sFlt-1, P-selectin, NGAL) at $11+0$ to $13+6$ weeks in the prediction of late (>34 weeks) pre-eclampsia. Prenatal diagnosis, 3, 1141-1146. https:// doi.org/10.1002/pd.2848

[14] Alekseeva L. L., Protopopova N. V. (2012). Sostoyanie platsentarnoi sistemy i gormonal'naya funktsiya platsenty u beremennykh $s$ arterial'noi gipertenziei v raznykh etnicheskikh gruppakh [The state of placental system and hormonal function of placenta at pregnant women with arterial hypertensia in different ethnic groups]. Journal of Siberian Medical Sciences, (1), 52. [in Russian].

[15] Sanghavi, M., Rutherford, J. D. (2014). Cardiovascular physiology of pregnancy. Circulation, 130(12), 1003-1008. https://doi.org/10.1161/ circulationaha.114.009029 